\title{
Public-Private Partnership in the Investment Sphere
}

\author{
Larysa L. HRYTSENKo ${ }^{i}$, OleKSANDRa I. TVEREZOVSKA ${ }^{i i}$
}

With reference of crisis's deepening processes at the present stage of national economy's development there is emerge a reduction in investment by both the private sector and public institutions. At the same time, one of the important components of creating a favorable climate for Ukraine's economic growth is the development of infrastructure. Up today a set of problems related to the fixed assets`obsolescence in almost all areas of economic activity, physical and moral deterioration of equipment, lack of investment in infrastructure, lack of budget funding for infrastructure investment and innovation projects, etc. Consequently, there is a need to find qualitatively new tools and mechanisms for investment development of Ukraine's economy, also forms and methods of investment interaction between the state and business based on public-private partnership (hereinafter - PPP). The effective interaction between the state and the private sector in PPP together with well-organized risk management system will allow investing in the development of production capacity, accelerate industrial growth, expand domestic and foreign markets, improve the quality of goods, works and services, improve public services, improve investment attractiveness and business activity. The research in the article is devoted to public-private partnership, which arises as a result of partnership between the state and business. PPP today is one of the qualitatively new tool and mechanism for investment development of Ukraine's economy. The world practice of PPP projects' application, their most widespread types in different countries is investigated in the work. At present PPP is quite widely, especially in Europe, in the implementation of socio-economic tasks, such as ensuring effective governance in the field of PPP, reducing burden on the budget, strengthening the social responsibility of business, improving the quality of life of the country`s population, etc.

Keywords: public private partnership, cooperation of the state and business, state policy, investments, investing, investment projects.

Abbreviations:

PPP - public-private partnership

УДК: $330.322: 334.7$

JEL Codes: C81, D81, G38, O12, O22

Introduction. Earlier research studies on public-private partnership indicated that the effective interaction between the state and the private sector in PPP will allow investing in the development of production capacity, accelerate industrial growth, expand domestic and foreign markets, improve the quality of goods, works and services, improve public services, investment attractiveness and business activity.

The factors discussed above will determine the relevance of this research about effective ways to implement PPP in Ukraine.

Problem statement. The analysis of the scientific literature on the research topic allows to assert that set of theoretical and practical problems concerning determining the main directions of PPP projects` dissemination and mechanisms of its implementation remain

${ }^{i}$ Larysa L. Hrytsenko, Doctor of Economics, Professor of the Department of Finance and Entrepreneurship, Sumy State University, Sumy;

ii Oleksandra I. Tverezovska, Student, Oleg Balatskyi Academic and Research Institute of Finance, Economics and Management, Sumy State University.

(c) L. L. Hrytsenko, O. I. Tverezovska, 2020.

https://doi.org/10.21272/mer.2020.89.12 
unresolved. Deficit of public finances and high deterioration of production and social infrastructure, including the need to restore the infrastructure of the regions in Ukraine defined the relevance of the study, its purpose, objectives and content.

The purpose of the article is to analyze the theoretical and methodological principles of PPP projects as a form of cooperation between the state and business in the context of the state policy`s implementation of national economy.

Results of the research. Reforming the state investment policy in the context of intensifying the interaction between the state and business involves the formation of partnership between the state and business. In the modern sense, the partnership of the public and private sectors means a form of cooperation between public authorities and the business world, which aims to provide funding, construction, restoration, management and governance [4].

As a rule in world practice, the term "public-private partnership" is considered in two senses: "first, it is a system of relations between state and business, which is widely used as a tool of national, international, regional, urban and municipal development; secondly, these are specific projects implemented jointly by state authorities and private companies at state and municipal property facilities" [17]. In highly developed countries, the term "public-private partnership" implies schemes of project implementation, a wide range of business models and relationships in any use of resources of the private sector (capital, know-how, managers' experience) for satisfaction social needs (roads, communications, real estate, etc.) [1].

A review of the literature indicates that the concept of "public-private partnership" is an ambiguous term with a set of interpretations that differ and can be used in different contexts.

The general definition of a public-private partnership presupposes that the relevant term is applied to "any duration cooperation between public and private sides, in which they jointly carry out activities for the production and sale of products and services, manage the common risks, costs and resources related to these products" $[5,16]$. The above statement, in our opinion, broadly and fully covers the diversity of all possible industrial relations between public and private organizations.

As a result of analyzing various scientists` interpretation of the PPP concept we can make an conclusion of results that researchers use this concept mainly in such fundamentally different contexts: as forms of interaction; as a public institution; as a transaction (Table 1).

According to the Law of Ukraine "On Public-Private Partnership", the signs of such a partnership are:

- provision of higher technical and economic indicators of efficiency of activity, than in a case of realization of such activity by the state partner without involvement of the private partner;

- duration of the relationship (from 5 to 50 years);

- transfer a part of the risks to the private partner in the process of PPP implementation;

- investment by a private partner in partnership objects from sources not prohibited by law [7].

A distinctive feature of the public-private partnership is that it is formed with aim to achieve both socially important and economically beneficial goals. The purpose of the partnership is to combine the best sides of the public and private sectors for mutual benefit, and the diversity of types, forms and areas of PPP's application make it a universal mechanism for developing new solutions for a set of long-term problems - from the creation and development of infrastructure to the development and adaptation of new promising 


\section{Л. Л. Гриценко, О. І. Тверезовська.}

Державно-приватне партнерство в інвестиційній сфері

technologies. Due to this, in the course of interaction between the state and business during the implementation of state investment policy the next issues are provided:

- innovative approach to solving problems of sustainable social development;

- expansion of the resource base due to access to technical, human, material and financial resources of all three sectors (state, business and society);

- mechanisms by which all components of the economic system are able to synergistically combine limited economic resources to effectively address the challenges;

- better use of the significance, values and qualities of each sector to create an integrated and sustainable society, taking into account general trends towards the convergence of socioeconomic phenomena [3].

Methodical approaches to the interpretation of the essence of PPP

Table 1

\begin{tabular}{|c|c|c|}
\hline Author and source & Definition & $\begin{array}{c}\text { Notes } \\
\text { (definition analysis) }\end{array}$ \\
\hline $\begin{array}{l}\text { Neikova I. (2010) Public-private } \\
\text { partnership as a component of the } \\
\text { investment mechanism of innovative } \\
\text { development. Scientific Bulletin of } \\
\text { the National University of the State } \\
\text { Tax Service of Ukraine (Economics, } \\
\text { Law), 1(48), 152-160 [11] }\end{array}$ & $\begin{array}{l}\text { PPP is an institutional alliance } \\
\text { between the state and business, which } \\
\text { is created for a certain period for the } \\
\text { implementation of a particular project } \\
\text { and ceases to exist after its } \\
\text { implementation }\end{array}$ & $\begin{array}{l}\text { This definition demonstrates PPP in } \\
\text { the segment of cooperation, in which } \\
\text { the state and the private sector } \\
\text { jointly implement socially } \\
\text { significant projects based on an } \\
\text { agreement on the division of tasks } \\
\text { and risks }\end{array}$ \\
\hline $\begin{array}{l}\text { Law of Ukraine \# 2404-VI "On } \\
\text { Public-Private Partnership" (July 1, } \\
\text { 2010) [7] }\end{array}$ & $\begin{array}{l}\text { PPP demonstrates cooperation } \\
\text { between Ukraine, the Autonomous } \\
\text { Republic of Crimea, territorial } \\
\text { communities represented by the } \\
\text { relevant state authorities and local } \\
\text { governments (state partners) and legal } \\
\text { entities, except on the basis of the } \\
\text { agreement in the order established by } \\
\text { this Law and other legislative acts }\end{array}$ & $\begin{array}{l}\text { This statement is more formal, } \\
\text { which has legislative force in } \\
\text { Ukraine }\end{array}$ \\
\hline $\begin{array}{l}\text { Polyakova O. (2009) Public-private } \\
\text { partnership in Ukraine: problems of } \\
\text { formation. Utilities of cities: } \\
\text { scientific and technical collection, } \\
(87), 317-322 \text { [13] }\end{array}$ & $\begin{array}{l}\text { Public institution, which includes a set } \\
\text { of formal and informal rules, within } \\
\text { which in order to meet the needs of } \\
\text { society is a joint activity of public } \\
\text { authorities and the private sector on } \\
\text { the basis of a set of alternatives to } \\
\text { treatment }\end{array}$ & $\begin{array}{l}\text { This interpretation already gives the } \\
\text { concept of the features of a social } \\
\text { institution }\end{array}$ \\
\hline \multirow{2}{*}{ The World Bank [1] } & $\begin{array}{l}\text { PPPs are agreements between the } \\
\text { public and private sides regarding the } \\
\text { production and provision of } \\
\text { infrastructure services, which are } \\
\text { concluded in order to attract } \\
\text { additional investment and, more } \\
\text { importantly, as a means of improving } \\
\text { the efficiency of budget funding }\end{array}$ & $\begin{array}{l}\text { This definition refutes the notion of } \\
\text { an agreement between the state and } \\
\text { business }\end{array}$ \\
\hline & $\begin{array}{l}\text { A long-term contract between a } \\
\text { private party and a governmental } \\
\text { entity for the provision of a public } \\
\text { asset or service, in which the private } \\
\text { party bears significant risk and } \\
\text { management responsibility and the } \\
\text { reward is related to performance }\end{array}$ & $\begin{array}{l}\text { This definition encompasses PPPs } \\
\text { that provide new assets and services, } \\
\text { and those for existing assets and } \\
\text { services. It can include PPPs in } \\
\text { which the private party is paid } \\
\text { entirely by service users, and those } \\
\text { in which a government agency } \\
\text { makes some or all of the payments }\end{array}$ \\
\hline
\end{tabular}


Such an instrument of interaction between the state and business as PPP creates new opportunities for social development in terms of better understanding of the activities and capabilities of each sector of the economy, as well as finding new ways its applying to achieve the common good.

For a long time in Ukraine the legal framework for the development of certain forms of PPP are taken shape. Currently, the legal basis for the development of PPP consists of: the Constitution of Ukraine, the Civil Code of Ukraine, the Commercial Code of Ukraine and others legislative acts of Ukraine.

In addition to laws, certain issues of PPP development are regulated by resolutions and orders of the Cabinet of Ministers of Ukraine, regulations and resolutions of central executive bodies, decisions of local executive bodies and local self-government bodies. In general, only at the national level, several dozen regulations governing PPP issues are defined.

The legal framework for regulating the development of PPPs in Ukraine is very complex, multilevel and bureaucratic, which in a high level of corruption creates risks for the effective use of this mechanism in the context of intensified investment activities. It can be argued that this is one of the factors of real PPP projects' limited amount, despite the significant interest from potential private partners.

Regarding the development of this form of cooperation between the state and the private sector in world practice, it should be noted that at present it is quite widely used, especially in Europe, in the implementation of socio-economic tasks, such as ensuring effective governance in the field of PPP, reducing burden on the budget, strengthening the social responsibility of business, improving the quality of life of the country's population, etc.

In view of that the World Bank recognized reforming and developing the infrastructure as one of the strategic direction to long-term economic growth, we can observe that the largest number of investment projects implemented within the system of PPP in European countries are projects in mention sphere. Besides all of this, such trend of infrastructure reforming can be treated as anti-crisis measures in the short term, as the implementation of large-scale infrastructure projects allows to create new jobs, improve the condition of metallurgy, construction, services, etc.

PPP projects are implemented in the transport sector, education and health care, housing and communal services, waste disposal, energy sector, etc. Regional features of public-private financing of infrastructure investment projects are also found in the context of individual sectors of the economy (Table 2).

The results demonstrated in the table below represent that in the field of aviation the largest number of investment PPP projects is implemented by the countries of Latin America and the Caribbean, as well as East Asia and the Pacific region, which account for $15 \%$. The countries of Europe and Central Asia account for only 9.3\% of PPP investment projects in this sector of the economy.

It is of importance that the dependence on these projects changes somewhat during their distribution in terms of countries`groups investment per 1 project. The most investmentintensive projects of this area are in the Middle East and North Africa, for which investments per 1 project amount to 2204.19 million dollars (average investments for this type of project in the world is 4212.09 million dollars) As well as there is a significant share of projects in South Asia - 700.74 million dollars per 1 project. Almost twenty-four times the average investment in aviation projects in sub-Saharan Africa is lower than the world average, for which the average investment in one project is only 117.83 million dollars. Such situation is caused by objective natural factors that complicate the process of development of the aviation industry in this region and increase investment needs. 
Л. Л. Гриценко, О. І. Тверезовська.

Державно-приватне партнерство в інвестиційній сфері

Table 2

The amount and volume of investments in PPP projects by regions of the world and sectors of the economy in 2000-2019 (compiled by the author based on [14])

\begin{tabular}{|c|c|c|c|}
\hline Region & $\begin{array}{c}\text { Number of } \\
\text { projects }\end{array}$ & $\begin{array}{c}\text { Investment volume, } \\
\text { million dollars }\end{array}$ & $\begin{array}{l}\text { The amount of investment } \\
\text { per } 1 \text { project, million dollars }\end{array}$ \\
\hline 1 & 2 & 3 & 4 \\
\hline \multicolumn{4}{|c|}{ Airports } \\
\hline East Asia and the Pacific & 25 & 6723.82 & 268.95 \\
\hline Europe and Central Asia & 13 & 3777.07 & 290.54 \\
\hline Latin America and the Caribbean & 63 & 35899.39 & 569.83 \\
\hline Middle East and North Africa & 21 & 46288.05 & 2204.19 \\
\hline South Asia & 11 & 7708.10 & 700.74 \\
\hline Sub-Saharan Africa & 7 & 1244.80 & 177.83 \\
\hline $\begin{array}{r}\text { Total } \\
\end{array}$ & 140 & 101641.23 & 4212.09 \\
\hline \multicolumn{4}{|c|}{ Collection and transport } \\
\hline East Asia and the Pacific & 3 & 19.68 & 6.56 \\
\hline Europe and Central Asia & 11 & 2385.12 & 216.83 \\
\hline Latin America and the Caribbean & 22 & 5950.52 & 270.48 \\
\hline Middle East and North Africa & 1 & 1.43 & 1.43 \\
\hline South Asia & 6 & 17.84 & 2.97 \\
\hline Sub-Saharan Africa & 0 & 0.00 & 0.00 \\
\hline $\begin{array}{r}\text { Total } \\
\end{array}$ & 43 & 8374.59 & 498.27 \\
\hline \multicolumn{4}{|c|}{ Railways } \\
\hline East Asia and the Pacific & 14 & 20914.12 & 1493.87 \\
\hline Europe and Central Asia & 5 & 4778.96 & 955.79 \\
\hline Latin America and the Caribbean & 148 & 41320.73 & 279.19 \\
\hline Middle East and North Africa & 2 & 247.0 & 123.50 \\
\hline South Asia & 34 & 33417.86 & 982.88 \\
\hline Sub-Saharan Africa & 15 & 6054.95 & 403.66 \\
\hline Total & 218 & 106733.62 & 4238.89 \\
\hline \multicolumn{4}{|c|}{ Water and sewerage } \\
\hline East Asia and the Pacific & 73 & 14253.09 & 195.25 \\
\hline Europe and Central Asia & 27 & 3489.71 & 129.25 \\
\hline Latin America and the Caribbean & 225 & 20337.03 & 90.39 \\
\hline Middle East and North Africa & 21 & 4469.23 & 212.82 \\
\hline South Asia & 499 & 14621.79 & 29.3 \\
\hline Sub-Saharan Africa & 16 & 3418.85 & 213.68 \\
\hline Total & 861 & 60589.70 & 870.68 \\
\hline \multicolumn{4}{|c|}{ Roads } \\
\hline East Asia and the Pacific & 109 & 62260.06 & 571.19 \\
\hline Europe and Central Asia & 16 & 13727.37 & 857.96 \\
\hline Latin America and the Caribbean & 209 & 120367.57 & 575.92 \\
\hline Middle East and North Africa & 10 & 23196.23 & 2319.62 \\
\hline South Asia & 510 & 112704.70 & 220.99 \\
\hline Sub-Saharan Africa & 11 & 2048.81 & 186.26 \\
\hline Total & 865 & 334304.74 & 4731.94 \\
\hline \multicolumn{4}{|c|}{ Electricity } \\
\hline East Asia and the Pacific & 556 & 138287.31 & 248.72 \\
\hline Europe and Central Asia & 457 & 66287.29 & 145.05 \\
\hline Latin America and the Caribbean & 1690 & 254411.69 & 150.54 \\
\hline Middle East and North Africa & 272 & 83254.56 & 306.08 \\
\hline
\end{tabular}


Larysa L. Hrytsenko, Oleksandra I. Tverezovska. Public-Private Partnership in the Investment Sphere

Table 2 (continued)

\begin{tabular}{|c|c|c|c|}
\hline Region & $\begin{array}{c}\text { Number of } \\
\text { projects }\end{array}$ & $\begin{array}{l}\text { Investment volume, } \\
\text { million dollars }\end{array}$ & $\begin{array}{l}\text { The amount of investment } \\
\text { per } 1 \text { project, million dollars }\end{array}$ \\
\hline 1 & 2 & 3 & 4 \\
\hline South Asia & 1034 & 194525.08 & 188.13 \\
\hline Sub-Saharan Africa & 252 & 42756.36 & 169.67 \\
\hline Total & 4261 & 779522.29 & 1208.19 \\
\hline \multicolumn{4}{|c|}{ General projects`amount in all sectors of the economy } \\
\hline East Asia and the Pacific & 780 & 242458.08 & 2784.54 \\
\hline Europe and Central Asia & 529 & 94445.52 & 2595.42 \\
\hline Latin America and the Caribbean & 2357 & 478286.93 & 1936.35 \\
\hline Middle East and North Africa & 327 & 157456.50 & 5167.65 \\
\hline South Asia & 2094 & 362995.37 & 2125.01 \\
\hline Sub-Saharan Africa & 301 & 55523.77 & 1151.10 \\
\hline Total & 6388 & 1391166.17 & 15760.07 \\
\hline
\end{tabular}

PPP investment projects in the field of collection and transport have not become widespread. Most of the projects are in Latin America and the Caribbean, which account for half of the industry's average investment. During the analyzed period (2000-2019), investment projects in this area in such regions as East Asia and the Pacific, the Middle East and North Africa were implemented in relatively small numbers, while in sub-Saharan Africa projects were not implemented at all. It should be noted that for investment projects in this area according to statistics are characterized by a high level of variation in the amount of investment per 1 PPP project by region of the world. On average, 498.27 million dollars was invested in 1 PPP project for the development of transport infrastructure in the world. But in sphere of roads communications were realized 865 PPP projects with total amount of investments 334304.74 million dollars. Mentioned above fact demonstrates that the countries worldwide paid enough attention to the issue of development road connection.

In the field of railway communication, the largest number of PPP projects and the largest amount of investments were made by the countries of Latin America and the Caribbean. They accounted for $68.0 \%$ of the total number of projects of this type and $39.0 \%$ of the volume of relevant investments. The least intensive investments in the railway sector are made by partners from the Middle East and North Africa, as well as Europe and Central Asia (its number is 2 and 5 investment projects for the entire analyzed period). Nevertheless, among the countries of the world the largest was the volume of investments per 1 project in the countries of East Asia and the Pacific region - 1493.87 million dollars (35\% of the total share of all investments per 1 project).

Public-private investment's analysis in the development of water and sewerage demonstrates that the most active are the countries of South Asia, where during 2000-2019 were realized 499 projects with a total volume of 14621.79 million dollars, which corresponds to $59.0 \%$ of the total number of projects in the world and $33.8 \%$ of the global investment of PPP in water supply and sewerage. Significant quantitative parameters of public-private investment in this area during analyzed period were also observed in Latin America and the Caribbean (225 projects and 20337.03 million dollars of investments). At the same time, the largest amounts of public-private investment in 1 project were made in the Middle East and North Africa (4 469.23 million dollars), and least at all in sub-Saharan Africa (3 418.85 million dollars). It is connected first of all with excellent qualitative characteristics of the corresponding projects. 
It should be noticed that Latin America and the Caribbean account for the largest share of total public investment in electricity: $32.6 \%$ or 254411.69 million dollars. However, in the regions of the Middle East and North Africa there are the largest amounts of investment per 1 project in this area of the economy. The amount of which is 306.08 million dollars.

Significant volumes are also invested in sphere of electricity by PPP projects of the countries of South Asia (194 525.08 million dollars or $25 \%$ of the total volume of investments in the corresponding direction). Investments in Europe and Central Asia per 1 project are quite poor, lower than the world average and amount to only 145.05 million dollars.

This analysis indicates that in general in the field of PPP the most active investors are South Asia countries, as well as Latin America and the Caribbean, which are leaders in the implementation of investment projects in all economic projects. The total number of PPP projects implemented in the countries of these regions is 478286.93 million dollars and 362995.37 million dollars respectively, with an average investment of 1 project 1936.35 million dollars and 2125.01 million dollars.

During 2000-2019 the countries of Europe and Central Asia implemented a total of 529 public-private partnership projects, but their funding per 1 project was higher than the world average and amounted to 2595.42 million dollars. The lowest number of projects was implemented in sub-Saharan Africa and the Middle East and North Africa, with a share of projects in the total number of projects worldwide of $5 \%$ and $4.7 \%$, respectively.

Among the analyzed sectors of the economy, the most involved in the field of investment in PPP is electricity. In this sphere was realized 261 projects with a total investment of 779522.29 million dollars. Likewise, a significant number of projects have been implemented in the sphere of road communication, as well as water supply and sewerage. Aviation and railway projects account for only $2.2 \%$ and $3.4 \%$, respectively. The least invested sector was collection and transport, where PPP implemented only 43 projects in the period from 2000 to 2019.

It is worthy of note that that the quantitative PPP indicators published by the World Bank and European organizations have some differences in indexes. According to European organizations, in general, a larger number of projects were implemented with correspondingly slightly inflated amounts of investment. This situation can be explained by the difference in the methodology of formation of generalizing indicators. When grouping projects by regions, the World Bank accepts the criteria of territorial affiliation of the project implementation site on a basis, as a same time as EU statistical organizations accept the factor of participation in the circle of public-private partners of non-resident residents of the place. In other words, EU statistics also consider a wide range of investment projects carried out within the framework of a public-private partnership with the participation of representatives of EU countries and had a cross-border character.

The main indicators that characterize the development of PPP with the participation of partners from EU countries, according to the European PPP Expertise Center are given in Table 3.

According to the date, which is demonstrated above, we can see that the annual number and volume of investment of infrastructure projects in the system of PPP with the participation of partners from EU countries tended to increase during 2000-2010.

In 2010-2019 the number of projects begins to decline significantly. According to the European PPP Expert Center (EPEC), the average annual growth rate of public-private investment in EU countries for the corresponding period was only $0.43 \%$. 
Larysa L. Hrytsenko, Oleksandra I. Tverezovska. Public-Private Partnership in the Investment Sphere

Table 3

The main indicators characterizing the development of PPP in Europe in 2000-2019 (compiled by the author based on [1])

\begin{tabular}{|c|c|c|c|c|}
\hline Year & $\begin{array}{c}\text { Number of } \\
\text { projects }\end{array}$ & $\begin{array}{c}\text { Investments, } \\
\text { million EUR }\end{array}$ & $\begin{array}{c}\text { Average investment per } \\
\text { project, million EUR }\end{array}$ & Investment growth rate \\
\hline 2000 & 91 & 1445.9 & 15.88901099 & X \\
\hline 2001 & 76 & 1326.9 & 17.45921053 & 1.278920793 \\
\hline 2002 & 77 & 1697 & 22,03896104 & 1.019033589 \\
\hline 2003 & 87 & 1729.3 & 19,87701149 & 0.920603712 \\
\hline 2004 & 119 & 1592 & 13,37815126 & 1.356469849 \\
\hline 2005 & 102 & 2159.5 & 21,17156863 & 1.216438991 \\
\hline 2006 & 136 & 2626.9 & 19,31544118 & 1.020023602 \\
\hline 2007 & 129 & 2679.5 & 20,77131783 & 0.882701997 \\
\hline 2008 & 107 & 2365.2 & 22,1046729 & 0.633899882 \\
\hline 2009 & 98 & 1499,3 & 15,29897959 & 1.220569599 \\
\hline 2010 & 106 & 1830 & 17,26415094 & 0.954863388 \\
\hline 2011 & 81 & 1747,4 & 21,57283951 & 0,691656175 \\
\hline 2012 & 62 & 1208,6 & 19,49354839 & 1,723150753 \\
\hline 2013 & 81 & 2082,6 & 25,71111111 & 0,761596082 \\
\hline 2014 & 76 & 1586,1 & 20,86973684 & 0,97919425 \\
\hline 2015 & 49 & 1553,1 & 31,69591837 & 0,687013071 \\
\hline 2016 & 64 & 1067 & 16,671875 & 1,223336457 \\
\hline 2017 & 33 & 1305,3 & 39,55454545 & 0,886922547 \\
\hline 2018 & 32 & 1157,7 & 36,178125 & 0,913189946 \\
\hline 2019 & 30 & 1057,2 & 35,24 & $\mathbf{x}$ \\
\hline Total & $\mathbf{1 6 3 6}$ & $\mathbf{3 3 7 1 6 , 5}$ & $\mathbf{4 5 1 , 5 5 6 1 7 6}$ & \\
\hline
\end{tabular}

In total, 1,636 PPP projects were implemented in the EU countries during this period, and public-private investments in the amount of 33,716.5 million EUR were made. At the same time, the average investment in 1 project will be 452 million EUR.

It should be noted that the greatest activity of EU countries in terms of public-private partnerships was observed during 2004-2010, with about 800 PPP projects worth a total of about 14,595 million EUR. This is primarily caused by the accession of 10 new members to the European Union, whose economy requires significant investment in the development of production and infrastructure. Its reduction since 2008 is a consequence of the global financial crisis, which has appreciably reduced the investment opportunities of PPP both in the EU and in the world. In the last decade, the dynamics have changed somewhat, the number of PPP projects has decreased, although their total cost was 14,595 million EUR.

A comparison of the dynamics of the total volume of investments in PPP projects implemented by the EU during 2000-2019 and the volume of investments per 1 project (Fig. 1) allows us to conclude that in Europe there was a gradual transition from the implementation of projects with huge amount of investments to projects with smaller investment needs.

Therefore, the territorial distribution of investments in public-private infrastructure projects with European countries is quite uneven. It reflects the different level of implementation of PPP mechanisms in national investment different state`s policies. 
Л. Л. Гриценко, О. І. Тверезовська.

Державно-приватне партнерство в інвестиційній сфері

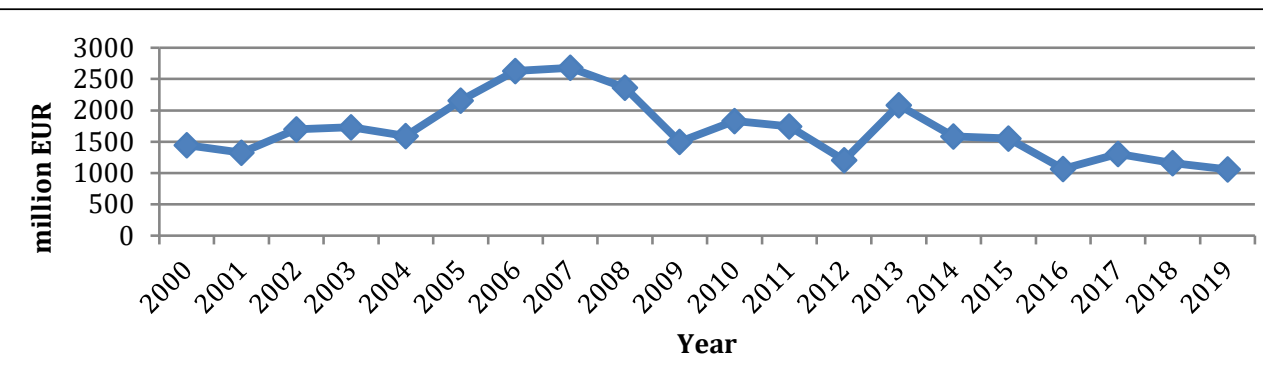

a) dynamics of total investment

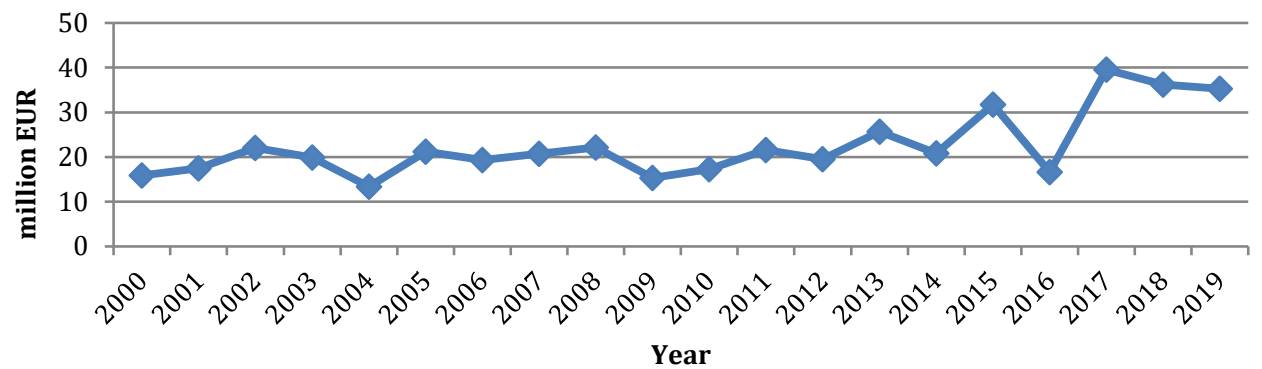

b) dynamics of the investments`volume per project

Figure 1. Dynamics of investment in PPP projects in Europe in 2000-2019

(built by the author based on [1])

Among European countries, the most active investment within the public-private partnership is carried out by the United Kingdom, which accounts for $40 \%$ of total investment, France $-13 \%$, Spain $-10 \%$ and Turkey $-9 \%$ (Fig. 2).

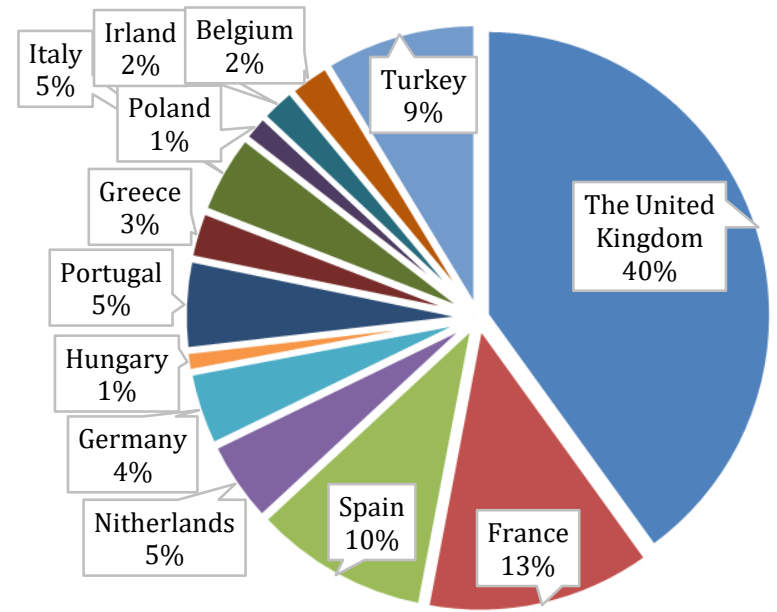

Figure 2. Structure of investments in public-private partnership projects by European countries in 2000-2019 (built by the author based on [2]) 
Visually, the differences in investment activity in the implementation of PPP projects in different countries of Europe are shown in Fig. 3.

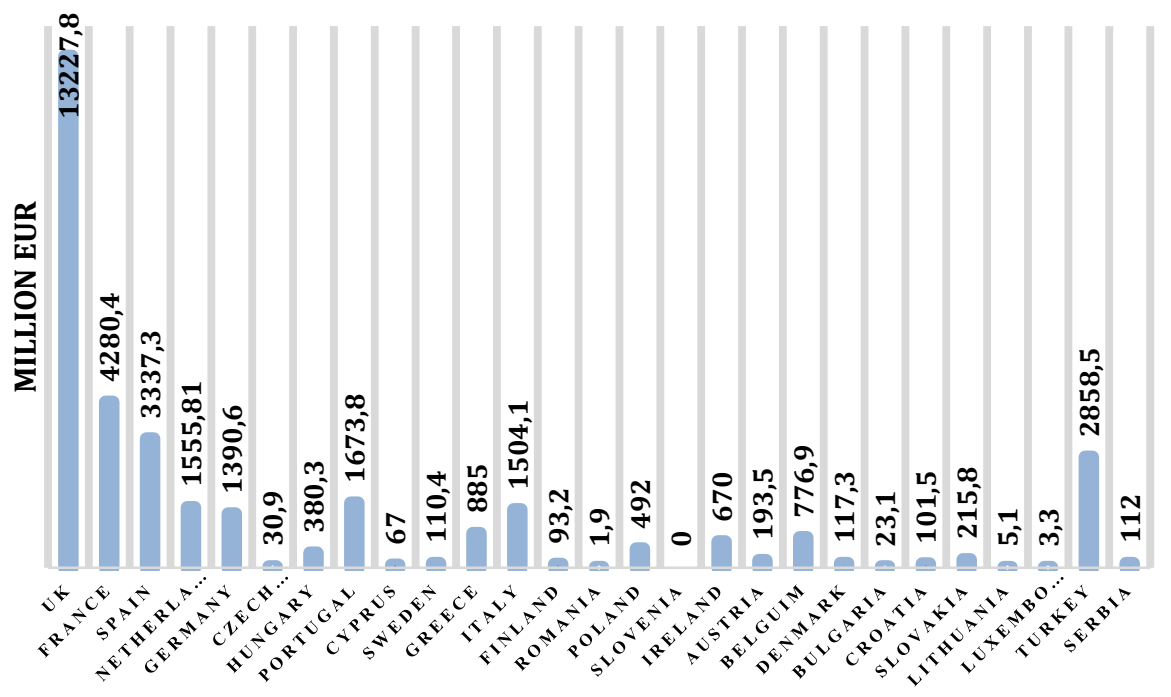

Figure 3. Comparison of the volume of investment of PPP projects in European countries during 2000-2019 (built by the author based on [2])

As it can be seen from Figure 3, in addition to the above-mentioned countries, Italy and Portugal also have volumes higher than the average level of public-private investment, and all other countries lag far behind in the implementation of public investment and business policy. At the same time, the volumes of public-private investments during 2000-2019 were rather low in Lithuania, Slovenia, Luxembourg, Romania and Bulgaria.

The main array of investment projects implemented by European countries is represented by transport projects. Proceeding from study, transport accounts for $20 \%$ of the total number of projects implemented in the system of PPP during 2000-2019. Its number takes 53\% of the total volume of relevant investments. This is evidence of the high capital intensity of this sector of the economy compared to others. Significant amounts of public-private investment are in projects in the field of health care (13\%), education (11\%) and the environment (6\%). At the same time, projects demonstrated in other areas have a lower capital intensity, as evidenced by the combination of low share of projects of this group in the total amount of capital invested by public and private partners $(2-4 \%$ of the total) in the total number of projects (up to $5 \%$ ) [2].

The results of the analysis of affluent countries and developing countries' economies indicate the presence of a dominant trend aimed at intensifying the processes of partnership between the state and business, which ensures the development and renewal of the national economy. This requires the state to implement a systematic and consistent public policy that considers various aspects of the nature of the partnership form of management. 
Speaking about level of development PPP projects, we can say that it is at a negligible level. The concept of PPP only begins its movement in comparison with well-developed European countries, where PPP has already become a successful tool for its economic and social growth.

Elaboration of PPP principals in Ukraine can become an key factor for infrastructure modernization, introduction of new methods and management models owned by the private sector, which are aimed to implement large programs and realize PPP projects, development the regulatory framework that the interaction of state partners with private partners and the main one - joint participation of the state, local self-government authorities and a private partner in scientific research.

At the same time, the main tasks that need to be solved for the development of PPP are: limited budget support in the financial crisis; imperfection of the legislation regulating the activity of the private sector in the field of PPP; distrust of private business to the state power, especially in the conditions of financial crisis and political instability in the country; insufficient preparation of local self-government authorities and private investors to use modern mechanisms of PPP; limited experience of successful cooperation between the state and local governments in the implementation of investment projects of public-private partnership; imperfect system of management of state and communal property; lack of adequate staffing in the use of public-private partnership mechanisms [15].

One of the important conditions for the development of PPP in Ukraine is the development of a comprehensive approach to assessing the investment attractiveness of investment projects that can be implemented as part of the program of public-private partnership aimed at the main direction. In the process of assessing the attractiveness of investment projects for participants in investing on the basis of interaction between the state and business and their selection for budget funding, considerable attention should be paid to the analysis of design and estimate documentation of projects, as well as research evaluation of the effectiveness of such investment projects [15].

The study of the impact of economic, political, legal, social, technological factors on the development of PPP in Ukraine, based on the method of extracting expert knowledge, PESTanalysis, analysis of indicators in global rankings allowed to determine the degree and nature of influence of factors on PPP development (Table 4) [15].

Table 4

Matrix of PEST-analysis of factors of macroenvironment of PPP development in Ukraine

\begin{tabular}{|c|c|}
\hline Political and legal factors (P) & Economic factors $(\mathrm{E})$ \\
\hline $\begin{array}{l}\text { Change of legislation (+); the probability of military } \\
\text { action in the country (-); bureaucratization and level } \\
\text { of corruption (-); institutional environment (-); } \\
\text { stability of tax policy (-); stability of political power } \\
\text { and the existing government (-); availability of } \\
\text { national and regional PPP development strategies }(+/- \\
) \text {; the level of business confidence in public } \\
\text { authorities }(+/-) \text {; system of state aid and provision of } \\
\text { state guarantees (-); availability of highly qualified } \\
\text { specialists in various sectors of the national economy } \\
\text { and PPP among state and local authorities }(+/-)\end{array}$ & $\begin{array}{l}\text { Inflation (-); dynamics of the hryvnia exchange rate (-); } \\
\text { monetary policy (-); fiscal policy (-); GDP dynamics (- } \\
\text { ); effective demand (-); the level of development of the } \\
\text { banking sector (the development of the market of long- } \\
\text { term liabilities and the level of lending to the real sector } \\
\text { of the economy) (-); tariffs for services of natural } \\
\text { monopolies (-); major currency rates; employment } \\
\text { dynamics (-); degree of openness of the economy }(+/-)\end{array}$ \\
\hline
\end{tabular}


Larysa L. Hrytsenko, Oleksandra I. Tverezovska.

Public-Private Partnership in the Investment Sphere

Table 4 (continued)

\begin{tabular}{|c|c|}
\hline Social factors $(\mathrm{S})$ & Technical factors $(\mathrm{T})$ \\
\hline $\begin{array}{l}\text { Society's need for quality infrastructure }(+) \text {; } \\
\text { population growth rates }(-) \text {; increase in the number of } \\
\text { temporarily displaced persons in the country }(+/-) \text {; } \\
\text { media influence }(+/-) \text {; society's attitude to PPP policy } \\
(+/-) \text {; the level of public awareness of the } \\
\text { effectiveness of PPP projects }(+/-)\end{array}$ & $\begin{array}{l}\text { Availability of technological support of public } \\
\text { authorities for the implementation of PPP projects (-); } \\
\text { feasibility study experience for PPP projects (-); access } \\
\text { to the latest technologies (+/-); level of innovation (-); } \\
\text { degree of use, implementation and transfer of } \\
\text { technologies (-) }\end{array}$ \\
\hline
\end{tabular}

Note: $(+)$ - positive impact, a factor that accelerates the development of PPP; $(-)$ - negative impact, a factor that inhibits the development of PPP; (+/-) - average value, depending on the situation [15].

The factors presented in the blocks are presented in descending order of their significance. This allowed us to identify the most significant factors that need to be focused on in shaping public policy on PPP development. The results of the expert assessment indicate that political, legal and economic factors have the greatest influence in Ukraine. The study of the nature of influence has shown that the social and political-legal spheres have the greatest number of positive factors, which means that society needs to develop partnership between government and business, and the state understands the importance of private partner involvement in socially important projects. A significant obstacle is the difficult economic situation in the country, which in turn significantly weakens the technological sphere, which is also a barrier to the development of PPP in Ukraine [15].

The economic effect for society from the partnership of the state and business is that it receives better public goods and services while reducing costs, improving social infrastructure, obtaining quality education and employment. The partnership not only promotes the development of market relations, but also private entrepreneurship and initiative. The development of the partnership is a rethinking of the relationship between the state and the private sector in order to form new mechanisms for managing the investment process in the national economy.

During strategy and tactics development of investment activities for private investors, it is advisable to carry out a comprehensive assessment of the risks of PPP and its distribution among partners. It will improve the quality of PPP risk management through quantitative and qualitative identification of the parameters of infrastructure investment projects, which are characterized by the risk of their deviation from the expected values.

As a rule the private sector pays considerable attention to the development of strategic guidelines in the form of a business plan (budget), in the process of formation of which it is important to substantiate the strategic directions of investment policy of the enterprise. Therefore, it is recommended that private business in the framework of public-private partnership projects use the methodological principles of forming a system for assessing the effectiveness of investment in the interaction of state and business in the investment sphere, based on the organization of the investment process and distribution of socio-economic effects, risks, responsibilities and competencies between the participants of public-private partnership in the implementation of infrastructure investment projects. The application of this approach will allow to identify the level of significance of public-private partnership projects, to select appropriate mechanisms for their financing and implementation.

Further research should focus on the development of scientific and methodological approaches to comprehensive assessment and systematic analysis of potential risks of publicprivate partnership projects related to the implementation of innovative developments and new technological processes. In concurrence with this, it is important to identify the main risk 
factors, to take into account changes in the impact factors specific to public-private partnership projects. It should be noted that domestic industrial enterprises are interested in finding investors and investing resources in the development of production facilities for the implementation of investment and innovation projects in energy efficiency, energy saving, etc.

Conclusions. Thus, combining the financial resources of the public and private sectors allows to realize the competitive potential of the national economy, to effectively solve economic and social problems. In particular, public-private partnership can be considered in modern conditions as one of the tools of state anti-crisis policy, as reasonable variation of its forms and models allows to change the state financial and social burden of the economy according to the economy.

As a consequence of research, it was determined that such a form of cooperation between the state and the private sector, as PPP, is widely used in world practice, especially in Europe, while as in Ukraine it movement begins to deal a turnover due to set of factors. The spheres of PPP projects are so huge, artificially from housing and communal services conclude transport sector and electricity.

Implementation and development of PPP in Ukraine will be accelerated provided that the necessary conditions and institutional and organizational elements of PPP formation are created.

In order to attract banking institutions and investors to effective cooperation and raising the system of public-private partnership to a qualitatively new level of development, the state should improve PPP mechanisms, develop a system for defining state priorities in the context of policy resettlement.

\section{References}

1. The World Bank. (2020). Retrieved from: https://ppi.worldbank.org/en/ppi.

2. European PPP Expertise Centre (2020). Retrieved from: http://www.eib.org/epec/.

3. Hryshchenko, S. (2011). Preparation and implementation of public-private partnership projects: a practical guide for local government and business. K.: Individual entrepreneur Moskalenko O. M.

4. Hrytsenko, L. (2012). Development of investment policy on the basis of interaction between the state and business: methodology and practice. $\mathrm{PhD}$ thesis. Sumy.

5. Klijn, E.-H., Teisman, G. (2003). Institutional and strategic barriers to public-private partnership: An analysis of Dutch cases. Public Money \& Management, 23(3), 137-145.

6. Law of Ukraine № 1039-XIV “On production sharing agreements” (December 29, 2019).

7. Law of Ukraine № 2404-VI “On Public-Private Partnership” (July 1, 2010).

8. Law of Ukraine № 2624-VI "On the peculiarities of the lease of facilities in the areas of heat supply, water supply and sewerage, which are in communal ownership" (October 20, 2019).

9. Law of Ukraine № 155-IX “On the concession” (October 3, 2019).

10. Lykhachev, V., Azanov, M. (2009). A practical analysis of modern mechanisms of public-private partnerships in foreign countries. Magazine "Finance, economics and security", 7-48.

11. Neikova, I. (2010) Public-private partnership as a component of the investment mechanism of innovative development. Scientific Bulletin of the National University of the State Tax Service of Ukraine (Economics, Law), 1(48), 152-160.

12. Pavliuk, A., Liapin, D. (2012). Regarding the development of public-private partnership as a mechanism for intensifying investment activity in Ukraine. Retrieved from https://niss.gov.ua/doslidzhennya/ekonomika/schodo-rozvitku-derzhavno-privatnogo-partnerstvayak-mekhanizmu-aktivizacii.

13. Polyakova, O. (2009). Public-private partnership in Ukraine: problems of formation. Utilities of cities: scientific and technical collection, 87, 317-322.

14. Private Participation in Infrastructure Projects Database (2020). Retrieved from https://ppi.worldbank.org/en/ppi. 
Larysa L. Hrytsenko, Oleksandra I. Tverezovska.

Public-Private Partnership in the Investment Sphere

15. Shemaieva, L. (2018) Public-private partnership as a tool for the development of the national economy. Abstract of the dissertation for the degree of Candidate of Economic Sciences. Kharkiv.

16. Van Ham, J. C. (2002). Building Public-Private Partnerships. Public Management Review: an international journal of research and theory, 3(4), 593-616.

17. Varnavskyi, V., Klumenko, A., Korolev, A. (2010). Public-private partnerships: theory and practice: a tutorial.

Manuscript received 10 May 2020

Государственно-частное партнерство в инвестиционной сфере

\title{
ЛАРИСА ЛЕОНИДОВНА ГРИЦЕНКО*, АЛЕКСАНДРА ИГОРЕВНА ТВЕРЕЗОВСКАЯ $* *$
}

\footnotetext{
* доктор экономических наук, профессор, профессор кафедры финансов и предпринимательства

Сумского государственного университета,

ул. Р.-Корсакова, 2, г. Сумы, 40007, Украина, тел.: 05032730 04, e-mail: l.hrytsenko@finance.sumdu.edu.ua

** магистрант Учебно-научного института финансов, экономики и менеджмента имени Олега Балачкого Сумского государственного университета,

ул. Р.-Корсакова, 2, г. Сумы, 40007, Украина,

тел.: 09589450 49, e-mail: tveresovskaja@gmail.com
}

В связи с процессами углубления кризисных явлений на современном этапе развития национальной экономики, происходит сокращение объемов инвестиций как со стороны частного сектора, так и со стороны государственных институтов. При этом одной из важных составляющих формирования благоприятного климата для экономического роста Украины остается развитие инфраструктуры. На сегодня продемонстрировано ряд проблем, связанных с устарелостью основных фондов практически во всех сферах экономической деятельности, физической и моральной изношенностью оборудования, отсутствием инвестиционных вложений в объекты инфраструктуры, недостаточностью бюджетного финансирования реализации инфраструктурных инвестиционных и инновационных проектов и т.п. Поэтому возникает необходимость поиска качественно новых инструментов и механизмов инвестиционного развития экономики Украины, форм и методов инвестиционного взаимодействия государства и бизнеса на основе системы государственно-частного партнерства. Исследования в статье посвящены государственночастному партнерству (далее - ГЧП), которое возникает в результате сотрудничества государства и бизнеса. ГЧП сегодня является одним из качественно новых инструментов и механизмов инвестиционного развития экономики Украины. В работе исследована мировая практика реализации проектов ГЧП, их наиболее распространенные типы в разных странах.

Ключевые слова: государственно-частное партнерство, сотрудничество государства и бизнеса, государственная политика, инвестиции, инвестирование, инвестиционные проекты.

\author{
Mechanism of Economic Regulation, 2020, No 3, 152-167 \\ ISSN 1726-8699 (print) \\ Державно-приватне партнерство в інвестиційній сфері \\ ЛАРИСА ЛЕОНІДІвНА ГРИЦЕНКО*, \\ ОЛЕКСАНДРА ІГОРІвНА ТВЕРЕЗОВСЬКА**, \\ * доктор економічних наук, професор, професор кафедри фінансів і підприємництва \\ Сумського державного університету,
}


Л. Л. Гриценко, О. І. Тверезовська.

Державно-приватне партнерство в інвестиційній сфері

вул. Р.-Корсакова, 2, м. Суми, 40007, Украӥна,

тел.: 05032730 04, e-mail: l.hrytsenko@finance.sumdu.edu.ua

**. магістрант Навчально-наукового інституту фінансів, економіки та менеджменту імені Олега Балацького Сумського державного університету,

вул. Р.-Корсакова, 2, м. Суми, 40007, Україна,

тел.: 09589450 49, e-mail: tveresovskaja@ gmail.com

У зв'язку з процесами поглиблення кризових явищ на сучасному етапі розвитку національної економіки, відбувається скорочення обсягів інвестицій як з боку приватного сектора, так і з боку державних інститутів. При цьому однією 3 важливих складових формування сприятливого клімату для економічного зростання України залишається розвиток інфраструктури. На сьогодні продемонстровано ряд проблем, пов'язаних із застарілістю основних фондів практично в усіх сферах економічної діяльності, фізичною та моральною зношеністю обладнання, відсутністю інвестиційних вкладень в об'єкти інфраструктури, недостатністю бюджетного фінансування реалізації інфраструктурних інвестиційних та інноваційних проектів тощо. Тому виникає необхідність пошуку якісно нових інструментів та механізмів інвестиційного розвитку економіки України, форм та методів інвестиційної взаємодії держави та бізнесу на основі системи державноприватного партнерства. Дослідження в статті присвячено державно-приватному партнерству (далі - ДПП), яке виникає в результаті співпраці держави та бізнесу. ДПП сьогодні є одним із якісно нових інструментів та механізмів інвестиційного розвитку економіки України. У роботі досліджено світову практику застосування проектів ДПП, їх найпоширеніші типи в різних країнах.

Ключові слова: державно-приватне партнерство, взаємодія держави та бізнесу, державна політика, інвестиції, інвестування, інвестиційні проекти.

JEL Codes: C81, D81, G38, O12, O22

Tables: 4; Figures: 3; References: 17

Language of the article: English

Лimepamypa

1. Офіиійний сайт Світового Банку [Електронний ресурс]. - Режим доступу : https://ppi.worldbank.org.

2. Портал даних Європейського центру експертизи ДПП [Електронний ресурс]. - Режим доступу : https://data.eib.org/epec.

3. Грищенко, C. Підготовка та реалізація проектів публічно-приватного партнерства : практичний посібник для органів місцевої влади та бізнесу / С. Грищенко. - К. : ФОП Москаленко О. М., 2011. - 140 с.

4. Гриценко, Л. Л. Розвиток інвестиційної політики на засадах взаємодії держави та бізнесу: методологія і практика : дисертація д-ра екон. наук, спец.: 08.00.03 - економіка та управління національним господарством / Л. Л. Гриценко; наук. керівник Т. А. Васильєва. - Суми : УАБС НБУ, 2012. $-506 \mathrm{c}$.

5. Klijn, E.-H. Institutional and strategic barriers to public-private partnership: An analysis of Dutch cases / E.-H. Klijn, G. Teisman // Public Money \& Management. 2003. - № 23 (3). - C. 137-145.

6. Закон України Про угоди про розподіл продукції : прийнятий 29 грудня 2019 р. № 1039-XIV [Електронний ресурс]. - Режим доступу : https://zakon.rada.gov.ua/laws/show/1039-14.

7. Закон України Про державно-приватне партнерство : прийнятий 1 липня 2010 p. № 2404-VI [Електронний ресурс]. - Режим доступу : https://zakon.rada.gov.ua/laws/show/2404-17.

8. Закон України Про особливості передачі в оренду об'єктів у сферах теплопостачання, водопостачання та водовідведення, що перебувають у комунальній власності : прийнятий 20 жовтня 2019 p. № 2624-VI [Електронний ресурс]. - Режим доступу : https://zakon.rada.gov.ua/laws/show/2624-17.

9. Закон України Про концесію : прийнятий 03 жовтня 2019 р. № 155-ІХ [Електронний ресурс]. Режим доступу : https://zakon.rada.gov.ua/laws/show/155-20. 
Larysa L. Hrytsenko, Oleksandra I. Tverezovska.

Public-Private Partnership in the Investment Sphere

10. Лихачев, В. Практичний аналіз сучасних механізмів державно-приватного партнерства в зарубіжних країнах / В. Лихачев, М. Азанов // Фінанси, економіка, безпека. 2009. - С. 7-48.

11. Нейкова, I. C. Державно-приватне партнерство як складова інвестиційного механізму інноваційного розвитку / І. С. Нейкова // Науковий вісник Національного університету ДПС України (економіка, право). 2010. - № 1(48). - С. 152-160.

12. Павлюк, $A$. Щодо розвитку державно-приватного партнерства як механізму активізації інвестиційної діяльності в Україні [Електронний ресурс] / А. Павлюк, Д. Ляпін // Аналітична записка. 2012. - Режим доступу : https://niss.gov.ua/doslidzhennya/ekonomika/schodo-rozvitkuderzhavno-privatnogo-partnerstva-yak-mekhanizmu-aktivizacii.

13. Полякова, О.М. Державно-приватне партнерство в Україні : проблеми становлення / О. М. Полякова // Коммунальное хозяйство городов : научно-технический сборник. - К. : Техніка, 2009. - № 87. - С. 317-322.

14. Проекти державно-приватного партнерства [Електронний ресурс]. - Режим доступу: https://ppi.worldbank.org/en/ppi.

15. Шемаєва, Л. В. Державно-приватне партнерство як інструмент розвитку національної економіки / Л.В. Шемаєва // Автореферат дисертації на здобуття наукового ступеня кандидата економічних наук. Харків, 2018. - 24 с.

16. Van Ham, J. C. Building Public-Private Partnerships / J. C. Van Ham // Public Management Review: an international journal of research and theory. 2002. - № 3 (4). - C. 593-616.

17. Варнавский, В. Г. Державно-приватне партнерство: теорія і практика: навчальний посібник / В. Г. Варнавский, А. В. Клименко, В. А. Корольов та ін. - М. : Вид. будинок Держ. ун-та Вищої школи економіки, 2010. - 287 с. 